"This is the peer reviewed version of the following article: Clark AH History Compass (2016) which has been published in final form at

http://onlinelibrary.wiley.com/doi/10.1111/hic3.12296/abstract. This article may be used for non-commercial purposes in accordance with Wiley Terms and Conditions for Self-

Archiving." 


\title{
Private Lives, Public History: Navigating Historical Consciousness in Australia
}

\begin{abstract}
:
Contests over Australian history captivate governments, historians and public commentators; they grab headlines and spawn endless public commentary. The "history wars', as those debates have come to be known, play out over museum exhibits, national commemorations, public apologies and the ways we teach the past to the next generation: should the National War Memorial commemorate the victims of the Australian frontier wars? Should Australians be sorry for historical actions in the past? Should Australian history be compulsory in school? (And so on.) But does that 'national story' have any meaning for Australian families and communities? This paper canvasses some recent qualitative research into historical consciousness in Australia to explore the ways those historical discourses operate beyond the public domain. It asks participants to speak in their own words about what history means: how they relate to their local and family histories, and how they engage with Australian history more broadly. Importantly, the project reveals a depth and complexity to Australians' historical engagement, and demonstrates that public and personal discourses about the past do indeed intersect in everyday life around the country.
\end{abstract}


Like many national narratives, Australian history clearly matters: the 'national story' captivates governments, enrages historians and public commentators, grabs headlines, and spawns endless public commentary. It divides and delights; it politicises and polarises. ${ }^{1}$ But does that 'national story' have any meaning for Australian families and communities? Are the historical questions it generates also debated in sports clubs, living rooms and community centre kitchenettes? Does it figure in everyday conversations? In other words, does that history matter for so-called 'ordinary people'?

Drawing on a qualitative national case study of historical consciousness in Australia, this paper looks at the relationship between personal and national historical engagement. The project it is based on, Private Lives, Public History, uses communitybased interviews along with a situational analysis to map (i) the ways Australians think about the nation's past in the context of their local and intimate narratives; and, concomitantly, (ii) whether their own historical connections are shaped by national and public histories. What is the personal impact of national memories such as Australia Day or the remembrance of Australia's war dead? Conversely, to what extent do family and community perspectives coalesce around broader public and collective memories? Understanding how people navigate the range of historical connections and disconnections across those public and private spheres frames this project and provides the rationale for its method and approach.

History is booming at a community level around the world, and Australia is no exception: there are thousands of local history groups and museums nationally, as well as genealogical societies and family history groups. The past is consumed on a grand scale, popularised by local and imported television programs, enjoyed by reading groups and heritage tours around the country. The growing digitisation of archives and reach of the Internet has also enabled unprecedented access for people to research and write their own family histories. ${ }^{2}$

In response to this popular interest in the past, several significant attempts have been made over the last twenty years to explore the historical consciousness of particular nations and communities. ${ }^{3}$ In 1998, American historians Roy Rosenzweig and David Thelen published the findings from a survey of around 1400 Americans that was motivated by a visible, yet mysterious social paradox: politicians railed over an apparent historical illiteracy among Americans, particularly schoolchildren, who seemed unfazed by their own historical ignorance; meanwhile, an explosion of historical production and consumption-what the authors termed 'popular history making'-was equally apparent. ${ }^{4}$ 
Rosenzweig and Thelen's study shifted dominant public and political questions over what people don't know about history to ask what do they know? It was a critical turning point in research into, and understandings of, historical consciousness, and it spawned several other national studies around the world. Based on that American project, Paul Ashton and Paula Hamilton undertook their 'Australians and the Past' project, interviewing hundreds of Australians about their relationships with the past. A further Canadian project was also completed using similar methodologies, surveying around 3,500 people throughout that country. ${ }^{5}$

These projects fundamentally challenged professional understandings about who practises 'history' and what constitutes historical knowledge. They revealed a distinct lack of community engagement with more formal national narratives as an international phenomenon, which people feel are too prescribed and disconnected from their everyday lives; and they noted a simultaneous popular contemplation of history that Ashton and Hamilton neatly termed 'past-mindedness'.6 The research showed an uneasiness, a 'Disjuncture between professional historical practice and "people's History" or history in the "everyday world"', Ashton and Hamilton further noted: one is official and knowledge-based-taught in schools, tested in surveys, and promoted by public institutions; the other is familiar, experiential, and tactile, and is deeply connected to people's families and communities. ${ }^{7}$

Yet in thinking through the Private Lives, Public History project I also wondered whether we might map that historical space not only as a disjuncture, but a possible intersection: do these distinct types of history ever come together? And if so, how? By way of answer, the project navigates everyday historical consciousness in order to understand the place and role of history in Australian society. The approach it uses could best be described as 'oral historiography': it employs qualitative research techniques of oral history and focus group work, along with critical analysis of public debates, to examine how people negotiate family and community histories as well as national narratives, and why. In short, it seeks to understand historical consciousness as a product of both intimate and public historical contexts.

This oral historiography reflects an interest in historical consciousness, as well as a desire to investigate historiography beyond the conventional spheres of academic or public debate. Using what Adele Clarke calls a 'situational analysis', it maps the attitudes of 'ordinary people' alongside public debates and discourses, contemplating themes of historical engagement and inheritance, as well as commemoration, historical contestation and consumption (through popular histories). ${ }^{8}$ 
Five communities were chosen to conduct this Australian case study using a purposive sampling method to generate a breadth of socio-economic, cultural and geographic background among participants: ${ }^{9}$ Marrickville (a multicultural municipality in inner Sydney), Chatswood (a community in Sydney's affluent north shore), Brimbank (a multicultural and working class community in outer western Melbourne), Rockhampton (a large rural town in central Queensland), and Derby (a remote town with a large Indigenous population in far north-western Australia). This was not to be a random or demographically representative cross-section of the Australian population, but a collection of participants-one hundred in total-who came from different generations, schooling, ethnic background and class, representing a diversity of voices and experiences.

Participants were approached through extant 'affinity groups'-community organisations such as seniors' centres and sporting clubs, education institutions such as universities and TAFEs, as well as migrant resource centres, youth groups and so on.10 Unlike several larger, mixed-methods studies of historical consciousness, the shape and size of this project was necessarily limited by its focus on non-directive, communitybased research, where I would essentially be 'listening in' on people's conversationsconversations that were critical to exploring intersections between community and public historical discourses. Such a grounded approach, across five very different communities with a wide range of participants, would inevitably reflect a diversity of voices and historical perspectives. The participants in this study are neither professional historians, politicians nor public commentators, but they do have opinions about Australian history that warrant acknowledgement and examination.

In their group interviews, participants were asked to discuss their attitudes and engagement with histories around them-intimate and personal, as well as national and public. Broadly, the characteristics of historical consciousness highlighted in earlier studies played out: these respondents did not readily engage with national historical narratives and sentiments unless they intersected with their own familial or community histories. Participants in this project confirm that intriguing historical paradox noted by others: collectively, they maintain deep historical connections day to day; they also express a distinct lack of engagement with more formal national narratives, which they consider to be much more prescribed and remote.

For example, these university students from Brimbank in Melbourne were very interested in questions of personal historical inheritance: 
Katy: I have a pendant that my mother received from Ireland when she was a baby. And because it was so expensive to send things over, my aunt sewed it into the gown of one of her baby outfits. She's passed it onto me, and I've passed it onto my daughter now.

Sylvie: That's nice.

Sandra: When I got married, my oma gave me her wedding ring. That's pretty special.

And yet, while history figures in these participants' lives, they don't particularly sense any collective inheritance of Australian history as a national narrative:

Do any of you feel connected to Australia's past?

All: No

Sylvie: Personally, no.

Why is that?

Sandra: I think, I don't know, for me, like, we never even really learnt much Australian history in school. I can't even remember learning about explorers, I mean, let alone Indigenous Australia, or anything.

A group of youth workers in St Albans also expressed an explicit lack of interest in an official national history:

Do any of you feel at all connected to Australia's past?

Adam: I don't feel particularly connected. Because I see myself as an Aussie and stuff, but like, my family tree and stuff just cut into Australia's history. So we weren't there from the beginning and we don't really have any Australian ancestors or anything like that. So I don't feel particularly connected, but it's interesting. It's not really a part of me so much.

Mike: The thing is, we all pretty much know the Australian history. The Hume and Hovell monument is over there [pointing], we know about the goldrush and all that stuff. But all that stuff happened however long ago, and all that stuff changes so quickly, it's just not us. We're us for us, not for what they were. 
Their comments give context to experiences of historical connectedness and disconnectedness in day-to-day life. These young Australians feel as if they have been exposed to an official national history, but that narrative doesn't properly speak to their own experiences-'it's just not us', as Mike admitted.

Australian history is taught in school-sometimes sporadically, sometimes repetitiously, it is emphasised in public historical celebrations and anniversaries, and it is bolstered by significant political funding. ${ }^{11}$ Despite that concerted effort, however, that narrative continues to languish in private, it seems. Jarrod, another young participant from Rockhampton, answered with similar reluctance when asked how connected he felt to Australian history: 'Um, I guess I have to be. I don't feel it, but I have to be because I was born and raised here. So I am part of it, whether I like it or not. I haven't got a choice, so yeah'. At the Derby Bowling Club, Simon expressed more interest and connection to his local community than a broader national story. 'I'm more interested in the local stuff. What happens outside of here probably doesn't concern us that much,' he said, before clarifying: 'That's probably the wrong way to say it. We all take notice of things that happen, it just doesn't mean as much as it does around the local area'.

This research confirms the historical contradiction that sees intimate and personal histories generating genuine, tangible engagement (as revealed in the interviews), while official histories frequently struggle for relevance and attachment in the community more broadly. Look a little closer, and that paradox seems to hinge precisely on participants' relationship to history-in particular, how it pertains to them and whether they can see themselves in it.

That distinction between the tactile, familiar inheritance people get from more local, personal histories and the relative detachment seen in disciplinary or official History (with a capital ' $\mathrm{H}$ ') has been widely noted in memory studies and public history. ${ }^{12}$ The question is, can personal and intimate historical connections be used to overcome this national historical reluctance? Or are they in fact part of the problem?

A number of historians have expressed concern that the increasing proliferation of popular and personal history-making may indeed be at the expense of broader historical engagement and critique. Responding critically to Rosenzweig and Thelen's research into everyday history in the United States, the historian Michael Kammen argues that 'family and pastness are clearly not the same as history and should not be conflated with it'.13 And in his influential book, Why History Matters, John Tosh ponders why, as a community, 'We are confronted by the paradox of a society which is immersed 
in the past yet detached from its history'. Echoing Kammen, Tosh insists that thinking 'about history' is not the same as 'thinking with history'. ${ }^{4}$ But is that all these participants are really doing?

It is worth asking because during these interviews it seemed that many respondents were working through some of the reasons behind that paradox of historical consciousness. A few even sought to explain why family history elicits such strong personal meaning. Do these family stories make you feel more connected to the past than, say, history that you learn in class? I asked Manisha, a university student from Brimbank. 'I think it's different,' she said, 'because you're connected to that history or that part of history, rather than history as a whole, you know what I mean? That's my personal view anyway.'

Douglas from Marrickville said that he felt connected to Australian history 'in an intimate unofficial way'. But in 'an official sense', he continued, 'I feel totally alienated from what it means to be an Australian'. Samantha, a schoolgirl from Chatswood, also spelled out how that point of historical relevance and connection was explicitly personal:

How about the history of your community or where you're from, whether here in Sydney or where your parents or grandparents originally came from? Does that interest you?

Samantha: Not really, because you don't really feel as strong a personal connection to it, and then, like, maybe you don't really feel affected by it, so you're not really interested.

Because it happened too long ago?

Samantha: Because it might not have directly happened to you.

Such comments confirm that 'sense of living connection' people make and maintain with their personal histories, as historian Marianne Hirsch observes in relation to intergenerational memory. 'Memory signals an affective link to the past,' she contends, 'a sense precisely of an embodied "living connection".'15

Indeed, when participants did connect to that broader Australian story it was generally through the prism of their own experience. After dismissing an overt connection with Australian history, Douglas from Marrickville offered this caveat: 'Well, I suppose I connect with it [Australian history] from my own local community, because I'm involved on the street, both creatively and socially with my community, and many of those people go back a long time. So I have that kind of connection.' 
Stacy's engagement with Australian history also emphasised the personal links from her forebears:

Do you feel particularly connected to Australian history?

Stacy: Definitely, definitely.

Why is that?

Stacy: Well, everyone's bragging about convicts these days, but because I did have ancestors coming out on the First Fleet, and probably being ninth generation Australian, I probably feel very Australian. So there's a very strong feeling of, um, I just want to know everything I can about Australian history.

Speaking among a group from a men's shed in Sydney's Chatswood, Nigel's generally 'negative' feelings towards Australian history were again shaped by family circumstances. Nigel criticised Australia's historical ties with Britain, and explained that his views were based on the fact that his grandfather had been badly injured under British command in World War I. Similarly, an Indigenous elder from Derby explained how her feelings about Australia Day (an annual national celebration that commemorates the arrival of the First Fleet in 1788) was inflected by the impact of colonisation on Indigenous people in particular. 'It doesn't mean a holiday to us,' said Violet, 'because it's a day Europeans come and take over the country, you know'.

Yet these results do raise some prickly historical questions: if people connect to the past through personal experience, is it possible to have historical critique and interrogation that doesn't offend or silence other people's 'pasts' and 'stories'? And if we are drawn to histories that connect us, how do we learn about histories that are less connected to us, but also deemed important? The project's findings reveal a depth and complexity to historical consciousness, demonstrating that public and personal discourses about the past do indeed intersect in everyday life around the country.

This study does not pretend its participants' perspectives equate to the sort of historical thinking we might expect from history graduates or scholars. While some historians worry that popular history privileges nostalgia over judgement and critique, it is also clear that this widespread public consumption of the past-what Jerome de Groot calls a historical 'enfranchisement'-sates a collective and individual desire to participate in memory making. History's increasing inclusivity has broadened not only access to historical practice but historical subjectivity itself. ${ }^{16}$ Treasuring granny's embroidery does not make us historians, per se. But it does reveal how historical 
connections are fostered. And it suggests that historians, education departments and governments intent on raising levels of historical knowledge ignore the nature of this relationship at their peril.

\footnotetext{
${ }^{1}$ Attwood, Telling the Truth About Aboriginal History; Clark, History's Children: History Wars in the Classroom; Curthoys, 'Disputing National Histories: Some Recent Australian Debates', pp. 6-18; Macintyre and Clark, The History Wars; McKenna, 'The History Anxiety', in A Bashford and S Macintyre (eds), The Cambridge History of Australia, pp. 561-580; Davison, The Use and Abuse of Australian History; Nobles, The Politics of Official Apologies.
}

${ }^{2}$ Sear, 'A Thousand Different Hands: History in Communities', pp. 198-214; Arrow, '“I Just Feel It's Important to Know Exactly What He Went Through": In Their Footsteps and Australian Television History'; Paul Ashton and Paula Hamilton, History at the Crossroads: Australians and the Past.

${ }^{3}$ In the words of Jörn Rüsen, a leading theorist of historical consciousness, the term can be best understood as "historical sense-generation". This making sense of the past, he suggests, is 'a mental procedure by which the past is interpreted for the sake of understanding the present and anticipating the future': 'Tradition: A principle of historical sense-generation and its logic and effect in historical culture', pp. 45-47. Rather than simply defining levels of attainment in historical literacy or understanding, he further (1987) argues that historical consciousness covers 'every form' of thinking about the past, from 'historical studies' to the "use and function of history in private and public life": "The Didactics of History in West Germany: Towards a New Self-Awareness of Historical Studies', p. 284.

${ }^{4}$ Rosenzweig and Thelen, The Presence of the Past: Popular Uses of History in American Life, p. 3. See also: Conrad, Létourneau, and Northrup, 'Canadians and Their Pasts: An Exploration in Historical Consciousness', pp. 19-20; Nash, Crabtree, and Dunn, History on Trial: Culture Wars and the Teaching of the Past; Ravitch and Finn, What Do Our 17-Year-Olds Know? A Report on the First National Assessment of History and Literature.

${ }^{5}$ Ashton and Hamilton History at the Crossroads, 54; Canadians and their Pasts: <http://www.canadiansandtheirpasts.ca/index.html>; Conrad, Létourneau, and Northrup, 'Canadians and Their Pasts: An Exploration in Historical Consciousness', 15-34; Conrad, et al., Canadians and Their Pasts.

${ }^{6}$ Ashton and Hamilton, History at the Crossroads, 10, 54. See also: Ashton \& Hamilton, 'At Home with the Past': 3, 5-30; Rosenzweig and Thelen, The Presence of the Past, 20; Rosenzweig, 'How Americans Use and Think about the Past', 273; Conrad, et al., Canadians and Their Pasts, 30-31.

${ }^{7}$ Ashton and Hamilton, History at the Crossroads, 8.

8 Adelle Clarke, Situational Analysis

9 Phillips and Smith, 'What is "Australian"? Knowledge and Attitudes Among a Gallery of Contemporary Australians', pp. 206-7.

${ }^{10}$ For a discussion of using affinity groups in qualitative research, see: Ipsos Mackay, The Mackay Report: Mind and Mood 2003, 4.

${ }^{11}$ Clark, History's Children.

${ }^{12}$ Hamilton, 'Memory Studies and Cultural History', pp. 81-97; Jensen, 'Usable Pasts: Comparing Approaches to Popular and Public History', pp. 42-56; Lowenthal, 'History and Memory', pp. 3143; Lowenthal, The Heritage Crusade and the Spoils of History; Nora, 'Between Memory and History: Les Lieux de Mémoire', pp. 7-24; Samuel, Theatres of Memory: Past and Present in Contemporary Culture, Theatres of Memory. 
${ }^{13}$ Conrad, Létourneau and Northrup, 'Canadians and Their Pasts'; Kammen, pp. 230-42;

Rosenzweig, 'Not a Simple Task: Professional Historians Meet Popular History-makers', pp. 35-8.

${ }^{14}$ Tosh, Why History Matters, p. 6.

${ }^{15}$ Hirsch, 'The Generation of Postmemory', p. 111.

${ }^{16}$ As Greg Dening once remarked, 'The most unhistorical thing we can do is to imagine that the past is us in funny clothes': Readings/Writings, p. 209. Ashton and Hamilton, History at the Crossroads, p. 34.

\section{Bibliography:}

Arrow, Michelle, “'I Just Feel It's Important to Know Exactly What He Went Through": In Their Footsteps and Australian Television History', Historical Journal of Film, Radio and Television, vol. 33, no. 4, 2013, pp. 594-611.

Ashton, Paul and Paula Hamilton, History at the Crossroads: Australians and the Past, Ultimo, NSW, Halstead Press, 2010.

, 'At Home with the Past: Background and Initial Findings from the National Survey', Australian Cultural History, no. 22, 2003, pp. 5-30.

Attwood, Bain, Telling the Truth About Aboriginal History, Crows Nest, NSW, Allen and Unwin, 2005.

Canadians and their Pasts: <http://www.canadiansandtheirpasts.ca/index.html>

Clark, Anna, History's Children: History Wars in the Classroom, Sydney, New South, 2008.

Clarke, Adelle E, Situational Analysis: Grounded Theory After the Postmodern Turn, Sage Publications, Thousand Oaks, CA, 2006.

Conrad, Margaret, et al., Canadians and Their Pasts, Toronto, University of Toronto Press, 2013.

Conrad, Margaret, Jocelyn Létourneau, and David Northrup, 'Canadians and Their Pasts: An Exploration in Historical Consciousness', The Public Historian, vol. 31, no. 1, 2009, pp. 15-34;

Curthoys, Ann, 'Disputing National Histories: Some Recent Australian Debates', Transforming Cultures eJournal, vol. 1, no. 1, 2006, pp. 6-18;

Davison, Graeme, The Use and Abuse of Australian History, Sydney, Allen \& Unwin, 2000.

Dening, Greg, Readings/Writings, Melbourne, Melbourne University Press, 1998.

Hamilton, Paula, 'Memory Studies and Cultural History', in R White and T-M Teo (eds), Cultural History in Australia, Cultural History in Australia, Sydney, UNSW Press, 2003, pp. 81-97.

Hirsch, Marianne, 'The Generation of Postmemory', Poetics Today, vol. 29, no. 1, 2008, pp. 103-28. Ipsos Mackay, The Mackay Report: Mind and Mood 2003, Sydney, Ipsos Mackay, 2003.

Jensen, Bernard Eric, 'Usable Pasts: Comparing Approaches to Popular and Public History', in P Ashton and H Kean (eds), People and Their Pasts: Public History Today, Basingstoke, Palgrave Macmillan, pp. 42-56.

Lowenthal, David, 'History and Memory', The Public Historian, vol. 19, no. 2, 1997, pp. 31-43.

Lowenthal, The Heritage Crusade and the Spoils of History, Cambridge, Cambridge University Press, 1998.

Macintyre, Stuart and Anna Clark, The History Wars, Carlton, Vic., Melbourne University Press, 2003. 
McKenna, Mark, 'The History Anxiety', in A Bashford and S Macintyre (eds), The Cambridge History of Australia, Port Melbourne, Cambridge University Press, 2013, pp. 561-580;

Nash, Gary B., Charlotte Crabtree, and Ross E.Dunn, History on Trial: Culture Wars and the Teaching of the Past, New York, Alfred A. Knopf, 1997.

Nobles, Melissa, The Politics of Official Apologies, New York, Cambridge University Press, 2008.

Nora, Pierre, 'Between Memory and History: Les Lieux de Mémoire', Representations, no. 26, 1989, pp. 7-24.

Phillips, Tim and Philip Smith, "What is "Australian"? Knowledge and Attitudes Among a Gallery of Contemporary Australians', Australian Journal of Political Science, vol. 35, no. 2: pp. 203-24.

Ravitch, Diane and Chester E. Finn Jnr, What Do Our 17-Year-Olds Know? A Report on the First National Assessment of History and Literature, New York, Harper \& Row, 1987.

Rosenzweig, Roy, 'How Americans Use and Think about the Past', in Peter Stearns, Peter Seixas and Sam Wineburg (eds) Knowing, Teaching and Learning History, New York, New York University Press, 2000, pp. 262-83.

' Not a Simple Task: Professional Historians Meet Popular History- makers', The Public Historian, vol. 22, no. 1, 2000, pp. 35-8.

Rosenzweig, Roy and David Thelen, The Presence of the Past: Popular Uses of History in American Life, New York, Columbia University Press, 1998.

Rüsen, Jörn, 'The Didactics of History in West Germany: Towards a New Self-Awareness of Historical Studies', History and Theory, vol. 26, no. 3, 1987, pp. 275-286.

,'Introduction: Historical Thinking as Intercultural Discourse', in Rüsen (ed.), Western Historical Thinking, New York, Berghan Books, 2002, pp. 1-14.

'Tradition: A Principle of Historical Sense-Generation and Its Logic and Effect in Historical Culture', History and Theory, vol. 51, 2012: 45-59.

Samuel, Raphael, Theatres of Memory: Past and Present in Contemporary Culture, Theatres of Memory: Past and Present in Contemporary Culture, London, Verso, 1994.

Sear, Martha, 'A Thousand Different Hands: History in Communities', in A Clark and P Ashton (eds), Australian History Now, Sydney, New South, 2013, pp. 198-214.

Tosh, John, Why History Matters, Bassingstoke, Palgrave Macmillan, 2008 